\title{
A Validated LC-MS/MS Method for the Estimation of Bortezomib and Bortezomib D3 (IS) in Human Plasma with Protein Precipitation and SPE Filter Cartridges
}

\author{
Bhetanabotla Chandramowli $^{1^{*}}$, Bigala B. Rajkamal ${ }^{2}$ \\ ${ }^{1}$ Mewar University, Gangrar, Chittorgarh, Rajasthan, India. \\ ${ }^{2}$ KVK college of pharmacy, Surmajiguda, Telangana, India.
}

\begin{tabular}{|c|c|}
\hline ARTICLE INFO & ABSTRACT \\
\hline Article history: & \multirow{12}{*}{$\begin{array}{l}\text { A simple, rapid, specific and precise liquid chromatography-tandem mass spectrophotometric (LC-MS/MS) } \\
\text { validated method was developed for quantification of Bortezomib in human plasma. Bortezomib D } 3 \text { was used as } \\
\text { internal standard, added to plasma sample prior to extraction using } 0.1 \% \text { formic acid in acetonitrile as a } \\
\text { precipitating agent. The interferences due to protein denaturation were removed using captiva SPE filter } \\
\text { cartridge of } 0.45 \mu \mathrm{m} \text {. Chromatographic separation was achieved on ACE } 5 \mathrm{CN} \text { column }(150 \mathrm{mmx} 4.6 \mathrm{~mm}) \text { with } \\
\text { acteonitrile: } 10 \mathrm{mM} \text { ammonium formate buffer }(75: 25 \mathrm{v} / \mathrm{v}) \text { as an isocratic mobile phase with a flow rate of } 1 \\
\mathrm{ml} / \mathrm{min} \text {. the LC eluent was split, and approximately } 0.1 \mathrm{ml} / \mathrm{min} \text { was introduced in to Tandem mass spectrometer } \\
\left.\text { using turbo Ion Spray interface at } 325^{\circ} \mathrm{C} \text {. Quantitation was performed by transition of } 367.3 \rightarrow 226.3 \mathrm{~m} / \mathrm{z}\right) \text { for } \\
\text { Bortezomib and } 370.3 \rightarrow 229.2(\mathrm{~m} / \mathrm{z}) \text { for Bortezomib D } 3 \text {. The concentrations of ten working standards showed } \\
\text { linearity between } 2 \text { to } 1000 \mathrm{ng} / \mathrm{ml}(\mathrm{r} 2 \geq 0.998) \text {. Chromatographic separation was achieved within } 3.5 \text { min. The } \\
\text { average extraction recoveries of three quality control concentrations were } 82.71 \% \text { for Bortezomib and were } \\
\text { within the acceptance limits. The coefficient of variation was } \leq 15 \% \text { for intra- and inter-batch assays. The assay } \\
\text { is suitable for pharmacokinetic study samples as demonstrated by its specificity, precision, accuracy, recovery, } \\
\text { and stability characteristics }\end{array}$} \\
\hline Received on: 24/03/2016 & \\
\hline Revised on: 16/05/2016 & \\
\hline Accepted on: 04/07/2016 & \\
\hline Available online: $31 / 01 / 2017$ & \\
\hline Key words: & \\
\hline Chlorella sp., Synechocystis & \\
\hline & \\
\hline wastewater. & \\
\hline & \\
\hline & \\
\hline & \\
\hline
\end{tabular}

\section{INTRODUCTION}

Bortezomib [(1R)-3-methyl-1-(\{(2S)-3-phenyl-2[(pyrazin-2-ylcarbonyl) amino] propanoyl $\}$ amino) butyl] boronic acid, is the first therapeutic proteasome inhibitor used for treating multiple myeloma. (Adams and Kauffman, 2004). Several UV-Visible (Venkat rao etal., 2012), HPLC (Appala raju et al., 2014; Brinda et al 2013; Srinivasulu et al., 2012; Rambabu et al., 2011) UFLC (Venkataramana et al., 2012) methods are available for quantification of bortezomib in its bulk and formulation dosage forms. Three LC-MS/MS(Liquid Chromatography coupled with Mass Spectroscopy) (Nix et al., 2001; Christos et al., 2004; Pekol et al., 2005) methods were reported for the estimation of bortezomib and isotope labeled

* Corresponding Author

E-mail: gipssrikanth@gmail.com bortezomib D3 (ISTD) from human plasma in gradient mode using buffer $\mathrm{A}(0.1 \%$ formic acid in water) and buffer $\mathrm{B}(0.1 \%$ formic acid in 90:10 acetonitrile and water) and samples were prepared by precipitating plasma proteins using chilled $0.1 \%$ formic acid in acetonitrile, chromatograms obtained on C18 column. Literature survey reveals, the reported Lc-ms/ms methods were suffered in preparing clean samples by protein precipitation extraction, shows plasma protein interference.

The aim of our study is to develop a validated (FDA guidelines, 2013) LC-MS/MS method and increasing the column life by removing interferences due to plasma protein denaturation using captiva SPE (Solid Phase Extraction) $0.45 \mu \mathrm{m}$ filter cartridge in sample preparation employing protein precipitation technique. The developed method was simple. Fast, accurate, specific and economical for the estimation of Bortezomib and Bortezomib D3 as internal standard (ISTD) from human plasma. 


\section{EXPERIMENT}

\section{Apparatus and software}

The HPLC system with an auto sampler was a Shimadzu LC- 20ADvp (Shimadzu, Japan) coupled with Applied Biosystem Sciex (MDS Sciex, Canada) API 3000 Tandem mass spectrometer. The auto sampler was SIL-HTC from Shimadzu, Japan. Captive SPE filtercatridge, $0.45 \mu \mathrm{m}$ from Agilent Technologies. The solvent delivery module was LC-20AD from Shimadzu, Japan. The chromatographic integration was performed by Analyst software (version: 1.4.2; Applied Biosystems).

\section{Chemicals and reagents}

Bortezomib and Bortezomib D3 (ISTD) were procured from Unichem Laboratories Ltd., Mumbai, India, Formic acid was procured from Merck Specialities Pvt. Ltd, Mumbai, India. Water used was collected from water purification systems (Milli Q, Milli Pore, USA) installed in laboratory. Methanol and acetonitrile were of HPLC grade and were supplied by J. T. Baker, USA. Pooled drug free expired frozen human plasma (K2-EDTA as anticoagulant) was obtained from St. Theresa Blood Bank, Hyderabad, was used during validation and study sample analysis. The plasma was stored into $-70 \pm 5^{\circ} \mathrm{C}$.

\section{Standards and working solutions Calibration standard Solutions}

Stock solutions of Bortezomib and Bortezomib D3 internal standard (ISTD) were prepared in methanol. Further dilutions were carried out in 50\% methanol. Calibration standards of ten concentration levels were prepared freshly by spiking drug free plasma with Bortezomib stock solution to give the concentrations of 2.00, 4.00, 8.00, 12.0, 25.0, 50.0, 100, 200, 500, and 1000ng/ml.

\section{Quality control standards}

Lowest quality control standards, Median quality control standards and highest quality control standards were prepared by spiking drug free plasma with Bortezomib to give solution containing 6,41 and $880 \mathrm{ng} / \mathrm{ml}$ respectively. They were stored at $20^{\circ} \mathrm{c}$ till the time analyzed.

\section{Chromatographic conditions}

Chromatographic separation was performed on a Hypurity ACE 5CN (150mmx4.6mm), analytical column and the mobile phase was a mixture of $0.10 \%(\mathrm{v} / \mathrm{v})$ formic acid in water to acetonitrile at a ratio of $25: 75, \mathrm{v} / \mathrm{v}$. Injection volume was $5 \mu \mathrm{L}$. The flow rate was $1.00 \mathrm{~mL} / \mathrm{min}$. Total analysis time of single injection was 3.00 minutes. Column oven temperature and auto sampler temperature was set to $40{ }^{\circ} \mathrm{C}$ and $5{ }^{\circ} \mathrm{C}$, respectively.

\section{Mass Spectrometric conditions}

The LC eluent was split, and approximately 0.100 $\mathrm{ml} / \mathrm{min}$ was introduced via electrospray ionization using a Turbo IonSpray interface set at $325{ }^{\circ} \mathrm{C}$ to generate positive ions
$[\mathrm{M}+\mathrm{H}]+$. Ionization was assisted with nebulizer and IonSpray gas (nitrogen) at 8 (arbitrary units) and 71/min, respectively. The IonSpray potential was maintained at $5 \mathrm{kV}$. During $\mathrm{ms} / \mathrm{ms}$ analysis, the collision energies used ranged from 18 to 25 V.

Quantification was performed by multiple reaction monitoring of the protonated precursor ion and the related product ion for Bortezomib using the IS method with a peak area ratios and a linear least-squares regression curve with weighting factor of $1 / x 2$. The mass transitions used for Bortezomib and Bortezomib D3 were $\mathrm{m} / \mathrm{z} \quad 367.3 \rightarrow 226.3$ and $\mathrm{m} / \mathrm{z} 370.3 \rightarrow 229.2$ respectively.

\section{Sample preparation method}

To $300 \mu 1$ of plasma, $50 \mu 1$ of bortezomib D3 $(5 \mu \mathrm{g} / \mathrm{ml})$ was added and vortexed. The drug was extracted with $2 \mathrm{ml}$ of $0.1 \%$ formic acid in acetonitrile, followed by centrifugation at 2000 $\mathrm{rpm} / \mathrm{min}$ on a cooling centrifuge for $15 \mathrm{~min}$ at $4^{0} \mathrm{c}$. The supernatant was withdrawn, filtered using captiva SPE filter catridge of $0.45 \mu \mathrm{m}$ and dried using lyophiliser. To the residue $150 \mu \mathrm{l}$ of mobile phase was added and respective samples were injected into column.

\section{VALIDATION}

\section{Specificity}

A solution containing $2.0 \mathrm{ng} / \mathrm{ml}$ was injected on to the column under optimized chromatographic conditions to show the separation of bortezomib from impurities and plasma. The specificity of the method was checked for the interference from plasma.

\section{Linearity}

Spiked concentrations were plotted against peak area ratios of bortezomib to internal standard and the best fit line was calculated .Wide range calibration was determined by solutions containing $2 \mathrm{ng} / \mathrm{ml}$ to $1000 \mathrm{ng} / \mathrm{ml}$.

\section{Recovery studies}

The $\%$ mean recoveries were determined by measuring the responses of the extracted plasma Quality control samples at High, Middle and Low (HQC, MQC and LQC) against un extracted Quality control samples at HQC, MQC and LQC.

\section{Precision and accuracy}

Intraday precision and accuracy was determined by analyzing quality control standards (6, 41and 880ng/ml) and LLOQ (Lower Limit of Quantification) Quality control standard $(2.00 \mathrm{ng} / \mathrm{mL})$ five times a day randomly, interday precision and accuracy was determined from the analysis of each quality control standards (6, 41and 880ng/ml) and LLOQ Quality Control standards $(2.00 \mathrm{ng} / \mathrm{mL})$ once on each of five different days. 


\section{Matrix effect}

The matrix effect for the intended method was assessed by using chromatographically screened human plasma. Concentrations equivalent to LQC and HQC of bortezomib were prepared with six different lots of plasma and are injected.

\section{Ruggedness}

Ruggedness was determined by analyzing six replicates of MQC in two batches using two different columns.

\section{Stability studies}

Short term (6 hours 38 minutes at ambient temperature) and long term ( 7 days below $8{ }^{\circ} \mathrm{C}$ ) stock solution stability was determined at concentration $1 \mathrm{mg} / \mathrm{ml}$ and $400 \mu \mathrm{g} / \mathrm{ml}$ for bortezomib and bortezomib D3 respectively. Stability was assessed by comparing against freshly prepared same stock solutions.

Freeze thaw stability of the spiked HQC and LQC samples was determined during three freeze thaw cycles stored below $-20{ }^{\circ} \mathrm{C}$. Stability was assessed by comparing against the freshly thawed quality control samples.

\section{RESULTS \& DISCUSSION}

The chromatography observed during the course of validation was acceptable and representative chromatograms of standard blank, LLOQ, HQC, MQC and LQC samples are shown in (Fig 1 to 2). The method developed was validated for specificity, accuracy \& precision, linearity and stability as per USFDA guidance. The results of validating parameters are given below.

\section{Specificity}

Six different lots of plasma were analyzed to ensure that no endogenous interferences were present at the retention time of bortezomib and bortezomib D3. Six LLOQ level samples along with plasma blank from the respective plasma lots were prepared and analyzed. (Table-1) shows results of specificity. In all plasma blanks, the response at the retention time of bortezomib was less than $20 \%$ of LLOQ response and at the retention time of IS, the response was less than $5 \%$ of mean IS response in LLOQ. The typical chromatogram of plasma blank (a) and chromatogram of LLOQ (b) was shown in (Fig 1).

\section{Linearity}

The calibration curve (peak area ratio Vs Concentration) was linear over working range of $2 \mathrm{ng} / \mathrm{ml}$ to $1000 \mathrm{ng} / \mathrm{ml}$ with ten point calibration used for quantification by linear regression, shown in (Fig 3). The regression equation for the analysis was $\mathrm{Y}=0.708 \mathrm{x}+3.864$ with coefficient of correction $\left(\mathrm{r}^{2}\right)=$ 0.998 .

\section{Recovery}

The \% mean recovery for bortezomib in LQC, MQC and HQC was $82.02 \%, 81.75 \%$ and $85.36 \%$ respectively (Table-2).

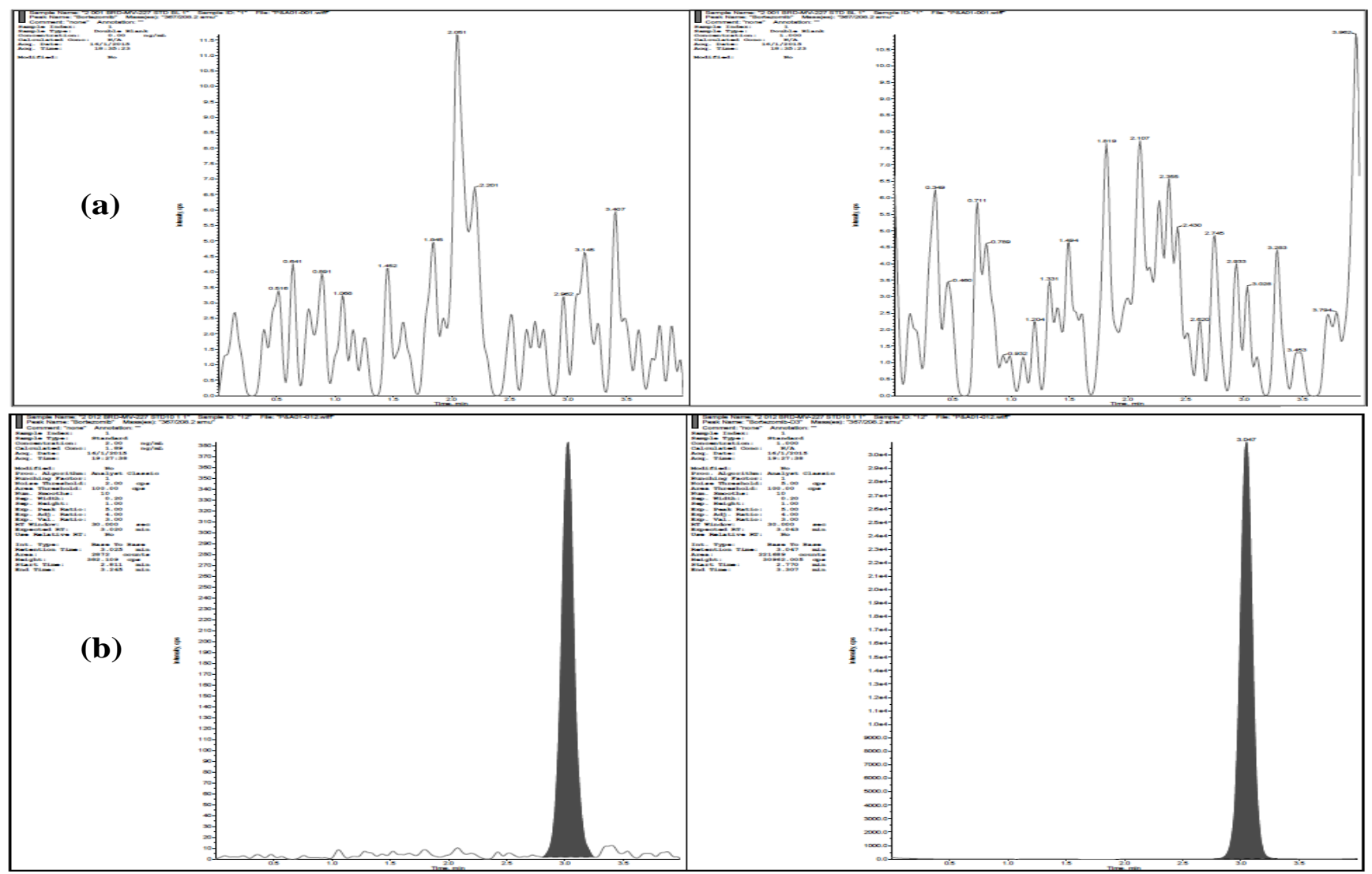

Fig. 1: Showing chromatograms of blank plasma (a) and spiked LLOQC (b) samples. 

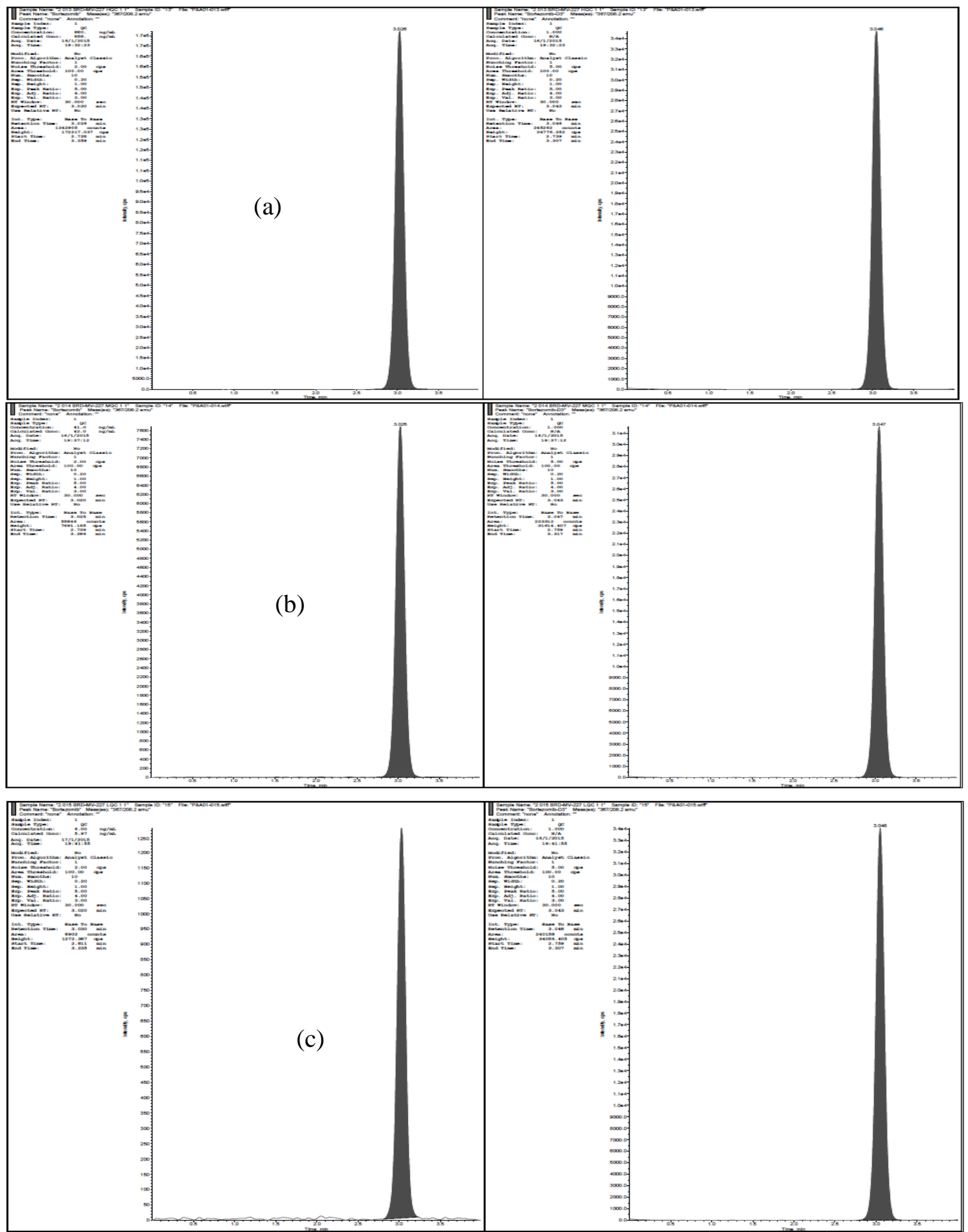

Fig. 2: Showing chromatograms of spiked HQC (a), MQC (b) and LOQC (c) samples

Table 1: Showing results of specificity for bortezomib and bortezomib D3(ISTD).

\begin{tabular}{|c|c|c|c|c|c|c|c|c|}
\hline \multirow{3}{*}{ S.No. } & \multicolumn{4}{|c|}{ Drug Response } & \multicolumn{4}{|c|}{ ISTD Response } \\
\hline & \multirow{2}{*}{$\begin{array}{c}\text { Area of STD } \\
\text { BL }\end{array}$} & \multicolumn{2}{|c|}{ LLOQ } & \multirow{2}{*}{$\%$ Interference } & \multirow{2}{*}{$\begin{array}{c}\text { Area of } \\
\text { STD BL }\end{array}$} & \multicolumn{2}{|c|}{ LLOQ } & \multirow{2}{*}{$\%$ Interference } \\
\hline & & Area & RT & & & Area & RT & \\
\hline 1 & 0 & 4821 & 3.024 & 0 & 0 & 354857 & 3.042 & 0 \\
\hline 2 & 0 & 5000 & 3.023 & 0 & 0 & 369547 & 3.042 & 0 \\
\hline 3 & 0 & 5099 & 3.023 & 0 & 0 & 385361 & 3.046 & 0 \\
\hline 4 & 0 & 4681 & 3.02 & 0 & 0 & 348594 & 3.045 & 0 \\
\hline 5 & 0 & 4856 & 3.016 & 0 & 0 & 360828 & 3.045 & 0 \\
\hline 6 & 0 & 4801 & 3.019 & 0 & 0 & 356700 & 3.043 & 0 \\
\hline
\end{tabular}




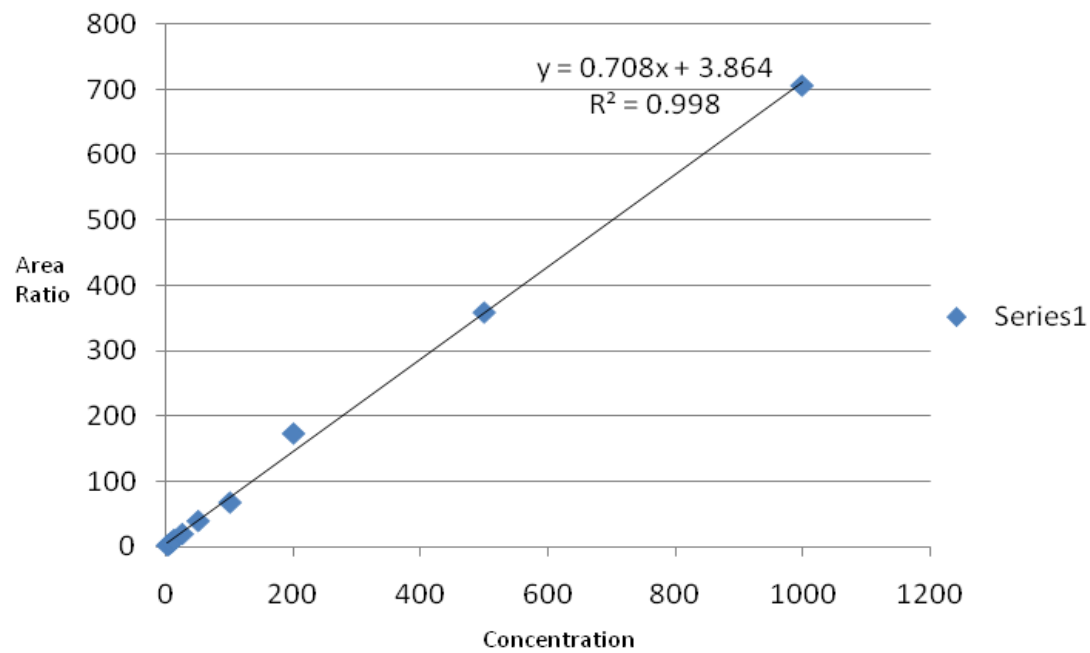

Fig. 3: Spiked concentrations ( $2 \mathrm{ng} / \mathrm{ml}$ to1000ng/ml) were plotted against peak area ratio Vs Concentration with ten point calibration used for quantification by linear regression.

Table 2: Showing \% Mean Recovery of bortezomib for LQC, MQC and HQC.

\begin{tabular}{|c|c|c|c|c|c|c|c|c|c|}
\hline \multirow{2}{*}{ S.NO } & \multicolumn{3}{|c|}{ LQC } & \multicolumn{3}{|c|}{ MQC } & \multicolumn{3}{|c|}{ HQC } \\
\hline & Un-Extracted & Extracted & \% Recovery & Un-Extracted & Extracted & \% Recovery & Un-Extracted & Extracted & \% Recovery \\
\hline 1 & 0.059 & 0.053 & 89.83 & 0.376 & 0.31 & 82.45 & 7.215 & 6.212 & 86.10 \\
\hline 2 & 0.059 & 0.046 & 77.97 & 0.385 & 0.304 & 78.96 & 7.284 & 6.301 & 86.50 \\
\hline 3 & 0.061 & 0.048 & 78.69 & 0.366 & 0.299 & 81.69 & 7.189 & 6.252 & 86.97 \\
\hline 4 & 0.057 & 0.044 & 77.19 & 0.361 & 0.304 & 84.21 & 7.289 & 5.992 & 82.21 \\
\hline 5 & 0.058 & 0.049 & 84.48 & 0.366 & 0.301 & 82.24 & 7.227 & 6.185 & 85.58 \\
\hline 6 & 0.059 & 0.046 & 77.97 & 0.378 & 0.306 & 80.95 & 7.282 & 6.176 & 84.81 \\
\hline Mean & 0.059 & 0.048 & 81.021 & 0.372 & 0.304 & 81.751 & 7.248 & 6.186 & 85.362 \\
\hline$\pm \mathrm{SD}$ & 0.001 & 0.003 & & 0.009 & 0.004 & & 0.043 & 0.106 & \\
\hline$\% \mathrm{CV}$ & 2.26 & 6.59 & & 2.45 & 1.27 & & 0.59 & 1.71 & \\
\hline
\end{tabular}

Table 3: Showing intraday and inter day Precision \& Accuracy of Quality Control Standards.

\begin{tabular}{|c|c|c|c|c|c|c|c|c|c|}
\hline Batch & QC ID & LQC & MQC & HQC & Batch & QC ID & LQC & MQC & HQC \\
\hline & Actual conc. $(\mu \mathrm{g} / \mathrm{mL})$ & 6 & 41 & 880 & & Actual conc. $(\mu \mathrm{g} / \mathrm{mL})$ & 6 & 41 & 880 \\
\hline & 1 & 5.97 & 42 & 858 & & 1 & 5.94 & 38.5 & 831 \\
\hline & 2 & 6.09 & 43.7 & 842 & & 2 & 5.72 & 40.5 & 799 \\
\hline & 3 & 6.07 & 42.1 & 855 & & 3 & 5.65 & 38.8 & 786 \\
\hline \multirow[t]{7}{*}{ Intra day } & 4 & 6.34 & 42 & 852 & Inter & 4 & 5.81 & 39.8 & 820 \\
\hline & 5 & 6.15 & 40 & 853 & day & 5 & 6.37 & 39.9 & 800 \\
\hline & 6 & 6.13 & 42.4 & 852 & & 6 & 5.88 & 39.9 & 834 \\
\hline & Mean & 6.107 & 42.033 & 852.0 & & Mean & 5.89 & 39.56 & 811.6 \\
\hline & $\pm \mathrm{SD}$ & 0.123 & 1.188 & 5.404 & & $\pm \mathrm{SD}$ & 0.255 & 0.75 & 19.48 \\
\hline & $\% \mathrm{CV}$ & 2.01 & 2.83 & 0.63 & & $\% \mathrm{CV}$ & 4.33 & 1.92 & 2.40 \\
\hline & $\%$ Accuracy & 101.79 & 102.52 & 96.81 & & $\%$ Accuracy & 98.25 & 96.50 & 92.23 \\
\hline
\end{tabular}




\section{Intraday and Inter-day Precision}

The intraday and inter-day precision and Accuracy of the method was found to be 0.63 to $4.33 \%$ and 92.23 to 102.52 respectively for the quality control samples. This is within the acceptance limits of precision is $15 \%$ and accuracy is 85 to $115 \%$ (Table-3). The limit of Quantification was found to be $2 \mathrm{ng} / \mathrm{ml}$. at such concentration the inter day precision was 3.64 and the accuracy was $95.5 \%$. Which are within the acceptance limits of precision is $20 \%$ and accuracy is 80 to $120 \%$ (Table-4)

Table 4: Precision \& Accuracy of LLOQC Standard.

\begin{tabular}{cc}
\hline & LLOQ \\
Actual conc.(ng/mL) & $\mathbf{2}$ \\
\hline 1 & 1.97 \\
2 & 1.81 \\
3 & 1.85 \\
4 & 1.84 \\
5 & 1.94 \\
6 & 1.96 \\
Mean & 1.910 \\
\pm SD & 0.069 \\
\% CV & 3.64 \\
\% Accuracy & 95.50 \\
\hline
\end{tabular}

\section{Matrix effect}

The \% CV for HQC and LQC samples was observed 0.72 and $1.7 \%$ respectively (Table-5), whichare within $15 \%$ as per the acceptance criteria.

Table 5: showing results of matrix effect obtained by preparing LQC and HQC with six different lots of plasma

\begin{tabular}{ccc}
\hline QC ID & LQC & HQC \\
\hline Actual conc. $(\mu \mathrm{g} / \mathrm{mL})$ & 6 & 880 \\
1 & 6.01 & 876 \\
2 & 6.2 & 868 \\
3 & 6.29 & 869 \\
4 & 6.25 & 859 \\
5 & 6.09 & 869 \\
6 & 6.21 & 876 \\
Mean & 6.175 & 869.500 \\
\pm SD & 0.105 & 6.285 \\
$\%$ CV & 1.70 & 0.72 \\
$\%$ Accuracy & 102.92 & 98.81 \\
\hline
\end{tabular}

\section{Ruggedness}

The ruggedness for two batches of MQC $(n=6)$ was obtained using two different columns. The $\%$ mean ruggedness for batch-1 MQC and batch-2 MQC were found 96 and 87 respectively (Table-6), which is within acceptance limits of 85 to $115 \%$.

Table 6: Showing the results of Ruggedness

\begin{tabular}{ccc}
\hline & MQC $(\mathbf{4 1} \mathbf{n g} / \mathbf{m l})$ & \\
\hline S.NO & $\begin{array}{c}\text { Column 1 } \\
\text { (area ratio) }\end{array}$ & $\begin{array}{c}\text { Column 2 } \\
\text { (area ratio) }\end{array}$ \\
\hline 1 & 40.4 & 39.4 \\
2 & 41.7 & 39.5 \\
3 & 40.9 & 39.4 \\
4 & 41.7 & 39.9 \\
5 & 41.1 & 40.7 \\
6 & 41.7 & 40.1 \\
Mean & 41.250 & 39.833 \\
\pm SD & 0.543 & 0.513 \\
$\%$ CV & 1.32 & 1.29 \\
\hline
\end{tabular}

\begin{tabular}{lll}
\hline$\%$ Accuracy & 100.61 & 97.15 \\
\hline
\end{tabular}

\section{Stability studies}

The $\%$ mean stability for 6 hours 38 minutes at ambient temperature was found as 100.11 and $93.59 \%$ for drug and ISTD respectively (Table-7) and the \% mean stability for 7 days at below $8^{\circ} \mathrm{C}$ was found as 100.07 and $101.15 \%$ for drug and ISTD respectively (Table-8), which is within the acceptance limits of 90 to $110 \%$.

The \% mean stability for HQC and LQC in Freeze Thaw Stability were 105 and 103 respectively (Table-9), which is within the acceptance limits of 85 to $115 \%$.

Table 7: Showing Short Term stock solution stability for bortezomib and bortezomib D3

\begin{tabular}{|c|c|c|c|c|}
\hline \multirow{4}{*}{ Replicate No. } & \multicolumn{2}{|c|}{$\begin{array}{c}\text { Bortezomib } \\
\begin{array}{c}\text { Nominal Concentration } \\
(\mathrm{mg} / \mathrm{mL})\end{array}\end{array}$} & \multicolumn{2}{|c|}{$\begin{array}{c}\text { Bortezomib-D3 (ISTD) } \\
\begin{array}{c}\text { Nominal Concentration } \\
(\mu \mathrm{g} / \mathrm{mL})\end{array}\end{array}$} \\
\hline & 1.00 & 1.00 & 400 & 400 \\
\hline & \multicolumn{2}{|c|}{ Area Ratio } & \multicolumn{2}{|c|}{ Area Ratio } \\
\hline & $\begin{array}{c}\begin{array}{c}\text { Comparison } \\
\text { Samples }\end{array} \\
\end{array}$ & $\begin{array}{l}\text { Stability } \\
\text { Samples } \\
\end{array}$ & $\begin{array}{c}\begin{array}{c}\text { Comparison } \\
\text { Samples }\end{array} \\
\end{array}$ & $\begin{array}{l}\text { Stability } \\
\text { Samples }\end{array}$ \\
\hline 01 & 6.293 & 6.237 & 0.185 & 0.173 \\
\hline 02 & 6.322 & 6.254 & 0.186 & 0.176 \\
\hline 03 & 6.137 & 6.142 & 0.189 & 0.178 \\
\hline 04 & 6.233 & 6.381 & 0.183 & 0.174 \\
\hline 05 & 6.233 & 6.255 & 0.192 & 0.174 \\
\hline 06 & 6.215 & 6.204 & 0.188 & 0.176 \\
\hline Mean & 6.2388 & 6.2455 & 0.1872 & 0.1752 \\
\hline SD & 0.06459 & 0.07878 & 0.00319 & 0.00183 \\
\hline$\% \mathrm{CV}$ & 1.04 & 1.26 & 1.70 & 1.05 \\
\hline$\%$ Mean Stability & 100.11 & & 93.59 & \\
\hline
\end{tabular}

Table 8: Showing long Term stock solution stability for bortezomib and bortezomib D3

\begin{tabular}{|c|c|c|c|c|}
\hline \multirow{4}{*}{ Replicate No. } & \multicolumn{2}{|c|}{$\begin{array}{c}\text { Bortezomib } \\
\begin{array}{c}\text { Nominal Concentration } \\
(\mathrm{mg} / \mathrm{mL})\end{array} \\
\end{array}$} & \multicolumn{2}{|c|}{$\begin{array}{c}\text { Bortezomib-D3 (ISTD) } \\
\text { Nominal Concentration } \\
(\mu \mathrm{g} / \mathrm{mL})\end{array}$} \\
\hline & 1.00 & 1.00 & 400 & 400 \\
\hline & \multicolumn{2}{|c|}{ Area Ratio } & \multicolumn{2}{|c|}{ Area Ratio } \\
\hline & $\begin{array}{c}\text { Comparison } \\
\text { Samples }\end{array}$ & $\begin{array}{l}\text { Stability } \\
\text { Samples }\end{array}$ & $\begin{array}{c}\text { Compariso } \\
\text { n Samples }\end{array}$ & $\begin{array}{l}\text { Stability } \\
\text { Samples }\end{array}$ \\
\hline 01 & 6.271 & 6.300 & 0.159 & 0.158 \\
\hline 02 & 6.203 & 6.182 & 0.161 & 0.160 \\
\hline 03 & 6.263 & 6.255 & 0.160 & 0.163 \\
\hline 04 & 6.372 & 6.134 & 0.157 & 0.165 \\
\hline 05 & 6.212 & 6.304 & 0.161 & 0.162 \\
\hline 06 & 6.251 & 6.424 & 0.160 & 0.161 \\
\hline Mean & 6.2620 & 6.2665 & 0.1597 & 0.1615 \\
\hline SD & 0.06047 & 0.10214 & 0.00151 & 0.00243 \\
\hline$\% \mathrm{CV}$ & 0.97 & 1.63 & 0.94 & 1.50 \\
\hline$\%$ Mean Stability & \multicolumn{2}{|c|}{100.07} & \multicolumn{2}{|c|}{101.15} \\
\hline
\end{tabular}

Table 9: Showing mean of three freeze thaw stability cycles of LQC and HQC

\begin{tabular}{lll}
\hline QC ID & LQC & HQC \\
\hline Actual conc. $(\mu \mathrm{g} / \mathrm{mL})$ & 6 & 880 \\
1 & 5.86 & 843 \\
2 & 5.95 & 845 \\
3 & 5.67 & 847 \\
4 & 5.92 & 850 \\
5 & 5.51 & 837 \\
6 & 5.53 & 845 \\
Mean & 5.740 & 844.500 \\
\pm SD & 0.196 & 4.370 \\
$\%$ CV & 3.42 & 0.52 \\
$\%$ Accuracy & 95.67 & 95.97 \\
\hline
\end{tabular}




\section{CONCLUSION}

The analytical method developed and validated for the quantitative determination of Bortezomib from plasma was simple, rapid, specific, sensitive, accurate and precise. Hence, the method is quite suitable to detect the drug from plasma samples of human volunteers.

\section{ACKNOWLEDGEMENT}

I am also grateful to my scholars and my friends for their kind help from time to time at each and every step of my project work.

\section{Financial support and sponsorship: Nil.}

Conflict of Interests: There are no conflicts of interest.

\section{REFERENCES}

Adams J, Kauffman M. Development of the proteasome inhibitor Velcade (Bortezomib). Cancer Invest, 2004; 22:304-11.

Appala Raju VVSS, Ahmed Bin Mohamud, Janaki Pathi P, Appala Raj N. The estimation of bortezomib in powder for injection dosage forms by rp-hplc,IJPA, 2014; 2:269-72.

Brinda MN, Krishna Reddy V, SasiKiran Goud E, Vinay Kumar K..Development and validation of rp-hplc method for determination of related substances of bortezomib in injection. World Journal of Pharmacy and Pharmaceutical Sciences, 2014; 3: 2521-29.

Christos N, Papandreou, Danai D, Daliani, Darrell Nix, Hong Yang, Timothy Madden, Xuemei Wang, Christine S, Pien, Randall E, Millikan, Shi-Ming Tu, Lance Pagliaro, Jeri Kim, Julian Adams, Peter Elliott, Dixie Esseltine, Alexandria Petrusich, Pauline Dieringer, Cherie Perez, Christopher J, Logothetis. Phase I Trial of the Proteasome Inhibitor Bortezomib in Patients With Advanced Solid Tumors With Observations in Androgen-Independent Prostate Cancer. J Clin Oncol, 2004; 33:210821.
FDA guideline, 2013. Guidance for industry: Bioanalytical method validation, US, FDA. Rockville, MD Nix DJ, Pien C, LaButti J. Clinical pharmacology of the proteasome inhibitor PS 341.

Proceedings of the 2001 AACR-NCI-EORTC International Conference on Molecular Targets and Cancer Therapeutics 7:11, 2001; (abstr 389)

Rambabu C, Venkatrao S, Ramu G, Ganesh M. Estimation of bortezomib in bulk and its pharmaceutical dosage forms by using a novel validated accurate reverse phase high performance liquid chromatography. Int J Pharm Pharm Sci, 2011; 3:24-29.

Srinivasulu K, Narasimha M, Rajasekhar K, Veerender M, Venkata Suryanarayana M. Development and Validation of a Stability Indicating LC Method for the Assay and Related Substances Determination of a Proteasome Inhibitor Bortezomib. Chromatography Research International, 2012; 2:1-13.

Teresa Pekol J, Scott Daniels, Jason Labutti, Ian Parsons, Darrell Nix, Elizabeth Baronas, Frank Hsieh, Liang-Shang Gan, Gerald Miwa.. Human metabolism of the proteasome inhibitor bortezomib: identification of circulating metabolites. Drug Metab Dispos, 2005; 33:771-77

Venkat Rao S, Srinivasarao M, RamuG, Rambabu C. UV Visible spectrophotometric determination of bortezomib in its bulk and formulation dosage forms. Der Pharmacia Letter, 2012; 4:720-27.

\section{How to cite this article:}

Chandramowli B, Rajkamal BB. A Validated LC-MS/MS Method for the Estimation of Bortezomib and Bortezomib D3 (IS) in Human Plasma with Protein Precipitation and SPE Filter Cartridges. J App Pharm Sci, 2017; 7 (01): 035-041. 